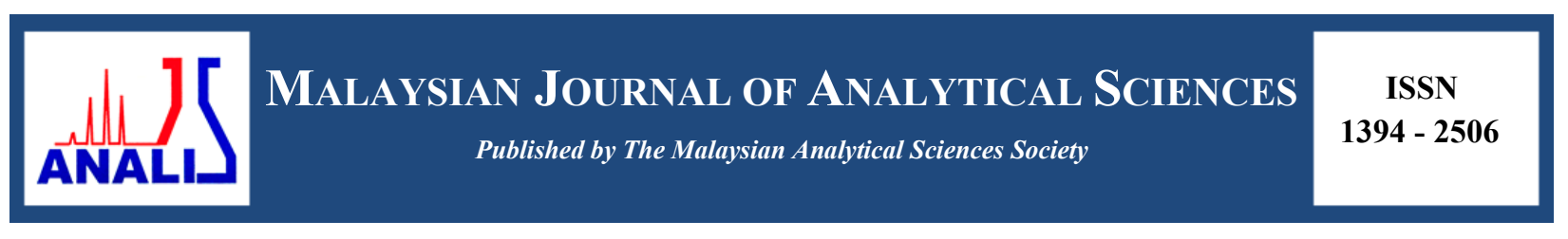

\title{
REMOVAL OF OIL AND GREASE AND ANIONIC SURFACTANTS IN SYNTHETIC CAR WASH WASTEWATER USING KAPOK FIBER: A BATCH-SCALE STUDY
}

\author{
(Penyingkiran Minyak dan Gris dan Anionik Surfaktan dalam Air Sisa Sintetik Basuhan Kereta \\ Menggunakan Fiber Kapok: Kajian Skala-Kelompok)
}

Muhammad Shahrul Shafendy Ibrahim* and Nor Haslina Hashim

Department of Civil Engineering Technology, Faculty of Engineering Technology,

Universiti Tun Hussein Onn Malaysia, 86400 Batu Pahat, Johor, Malaysia

*Corresponding author: msshafendy2@gmail.com

Received: 16 April 2017; Accepted: 7 March 2018

\begin{abstract}
Kapok fiber (Ceiba pentandra) is a natural sorbent that exhibits excellent hydrophobic-oleophilic characteristics. The effects of dosage, and contact time were studied in a batch study. The initial and final concentration of the oil and grease and anionic surfactants in the synthetic car wash wastewater were evaluated to determine the removal efficiency of Kapok fiber. The results show excellent performance of Kapok fiber in removing oil and grease up to $100 \%$, achieved using $0.1 \mathrm{~g}$ with 10 minutes contact time. Meanwhile, highest removal of anionic surfactants was up to $46 \%$, achieved using $3.0 \mathrm{~g}$ of Kapok fiber with 10 minutes contact time. Overall, Kapok fiber showed great potential as an effective oil and grease, and anionic surfactants adsorbent.
\end{abstract}

Keywords: wastewater treatment, car wash wastewater, Kapok fiber, oil and grease, anionic surfactants

\section{Abstrak}

Serat Kapok (Ceiba pentandra) adalah penyerap semulajadi yang mempamerkan ciri-ciri hidrofobik-oleofilik cemerlang. Kesan dos, dan masa tindak balas dikaji dalam kajian skala kelompok. Kepekatan awal dan akhir kehadiran minyak dan gris surfaktan anionik dalam air kumbahan sintetik disediakan telah dinilai untuk menentukan kecekapan serat Kapok. Keputusan menunjukkan prestasi yang sangat baik serat Kapok dalam mengeluarkan minyak dan gris dan surfaktan anionik. Penyingkiran minyak dan gris sehingga $100 \%$ telah dicapai dengan menggunakan $0.1 \mathrm{~g}$ dengan masa tindak balas selama 10 minit, manakala penyingkiran surfaktan anionik sehingga 46\% telah dicapai dengan menggunakan 3.0 g serat Kapok dengan masa 10 minit kenalan. Secara keseluruhan, serat Kapok berpotensi tinggi sebagai minyak dan gris yang berkesan dan penjerap surfaktan anionic yang berkesan.

Kata kunci: rawatan air sisa, air sisa basuhan kereta, serat Kapok, minyak dan gris, surfaktan anionik

\section{Introduction}

Car wash stations has been one of the many uprising service abundance in every city [1]. The car wash industry uses huge amount of water during the cleaning process. The usage of various chemical agents for cleaning and appealing efforts also contributes to deterioration of the environment. After the cleaning process, large quantities of surfactants are discharged into aquatic and terrestrial environments [2]. Oil and grease in car wash wastewater can originate from various kind of the petroleum-based products on the surface of vehicle or might also leaked out from 
the motor engine [3]. Moreover, there is also a chance for the wastewater from the car wash station to contain hydraulic fluid and motor oil, which could have leaked out of the braking system and engine [4]. Generally, the composition of oil and grease is too complex due to the reason that it can contain lots of hazardous materials (such as phenols and polyaromatic hydrocarbons) which are carcinogenic to humans $[3,5,6]$.

In addition, anionic surfactants were also produced in car wash cleaning processes [7]. Among the different type of surfactants, anionic surfactant can be considered as very important due to reason of it being responsible for $60 \%$ of the world soap production [8]. The anionic surfactants are known to have potential to cause skin irritation and it also shows obvious biological activity with various bioactive macromolecules such as starch [9] and proteins [10] or being introduced into various cell fragments thus causing malfunction as reported accordingly. Overall, the impacts of contaminants that originated from car wash wastewater can be as light as irritation to fatal (towards aquatic organisms). Thus, an efficient and cost-friendly treatment for the wastewater produced from car wash station should be established and practiced.

Among the natural fibres used in wastewater treatment, Kapok fiber is a natural hollow fiber which can be yielded from the seedpod of Kapok tree. Kapok trees belong to the family of Bombaceae, which can be cultivated in Asia, Africa and South America. Kapok fiber is composed of single-cell plant fibers that contains lignin and not attached to the seed grains. Visually, Kapok is a yellowish or light-brown silky fiber that covers the seeds of Kapok trees. In wastewater treatment industry, due to its unique properties (chemical and physical traits), Kapok fiber-based materials have offered potentials for new application as oil absorbent, thus highlighting Kapok fiber in recent years [11]. The wax layer exhibiting the surface of Kapok fiber enables the fiber to have excellent hydrophobic-oleophilic features and thus making Kapok fiber a fascinating medium for oil-sorbent application [12,13]. The objectives of this work are to assess the potential of Kapok fiber for the removal of oil and grease, and anionic surfactants in synthetic car wash wastewater. Effects of adsorbent dosage, and contact time were studied.

\section{Materials}

\section{Materials and Methods}

In this work, natural Kapok fiber were screened (for impurities; dusts and lumps) and dried at $40{ }^{\circ} \mathrm{C}$ for a day before used [14]. To ensure freshness of the raw fiber, no further treatment was done on the Kapok fibers [12]. The Kapok fiber was obtained from a local supplier in Batu Pahat, Johor.

\section{Chemicals}

Sodium dodecyl sulphate (SDS), diesel oil, n-hexane, methyl-tert-butyl ether (MTBE), sodium sulphate anhydrous crystal, chloroform, and methylene blue.

\section{Preparation of synthetic wastewater}

Synthetic car wash wastewater was prepared based on the actual car wash wastewater was obtained from a local car wash station which was analysed for its oil and grease concentration (Average $=246.7 \mathrm{mg} / \mathrm{L}$, Median $=\sim 200 \mathrm{mg} / \mathrm{L}$, $\mathrm{n}=5$ ) and anionic surfactants (Average $=115.3 \mathrm{mg} / \mathrm{L}$, Median $=\sim 100 \mathrm{mg} / \mathrm{L}, \mathrm{n}=5$ ).

\section{Oil and grease synthetic wastewater}

An amount $200 \mathrm{mg} / \mathrm{L}$ of oil and grease synthetic wastewater was prepared by weighing $0.2 \mathrm{~g}$ of diesel oil and mixing it with $500 \mathrm{~mL}$ ultrapure water. The diesel oil was chosen to be used as the source of oil and grease for the synthetic wastewater due to its characteristics that can represents low viscosity oils such as light crude oil, kerosene and gasoline [15]. Next, the mixture was blended using a blender to form an emulsion. The mixture was then poured into a $1000 \mathrm{~mL}$ volumetric flask. The volumetric flask was top up with ultrapure water to the mark. Next, the $\mathrm{pH}$ of the solution was adjusted to 7 .

\section{Anionic surfactants synthetic wastewater}

An amount $100 \mathrm{mg} / \mathrm{L}$ of anionic surfactants synthetic wastewater was prepared by dissolving $0.1 \mathrm{~g}$ of SDS powder in $100 \mathrm{~mL}$ ultrapure water in $1000 \mathrm{~mL}$ volumetric flask [16]. Then, the volumetric flask was top up with ultrapure water to the mark. Next, the $\mathrm{pH}$ value of the solution was adjusted to 7 . 


\section{Evaluation of removal efficiency: Removals of oil and grease}

An amount $150 \mathrm{~mL}$ of freshly prepared oil and grease synthetic wastewater was poured into a conical flask. Various dosage of dried Kapok fiber were added into the conical flask $(0.1 \mathrm{~g}, 1.0 \mathrm{~g}$ and $3.0 \mathrm{~g})$. Each conical flask containing the samples were shaken for 10,30 and 60 minutes. The conical flasks containing the samples were shaken using orbital shaker at $120 \mathrm{rpm}$. Each set of experiment was done in triplicate to provide reliable data.

\section{Removals of anionic surfactants}

An amount $150 \mathrm{~mL}$ of freshly prepared SDS synthetic wastewater were poured into conical flasks separately. Various dosage of washed and dried Kapok fiber were added into the conical flask $(0.1 \mathrm{~g}, 1.0 \mathrm{~g}$ and $3.0 \mathrm{~g})$. Each sample were shaken for 10, 30 and 60 minutes. The conical flasks containing the samples were shaken using orbital shaker at $120 \mathrm{rpm}$. Each set were done in triplicates to provide reliable data.

\section{Data analysis}

The method used to determine the concentration of oil and grease in the treated and untreated samples was as according to the standard method APHA 2005 [17]. An amount $30 \mathrm{~mL}$ of each sample was pipetted into a separatory funnel. The oil and grease in the samples were then extracted using a mixture of n-hexane and MTBE ( $80 \%$ n-hexane: $20 \%$ MTBE). The organic layer was then filtered through a filter paper filled with sodium sulphate (to absorb water residue) into an empty beaker (previously weighed). The organic solvents were then evaporated in a water bath at $85{ }^{\circ} \mathrm{C}$. The weight of the beaker with the oil residue were recorded. The concentration of oil and grease were calculated using equation 1 :

$$
\text { Oil and Grease, } \mathrm{mg} / \mathrm{L}=\frac{(A-B) \times 1000}{\text { Volume of sample }(\mathrm{mL})}
$$

where $\mathrm{A}$ is defined as final weight of beaker and $\mathrm{B}$ is initial weight of beaker

The method used to determine the concentration of anionic surfactants in the treated and untreated samples was the standard method APHA 2010 [17]. $10 \mathrm{~mL}$ of each sample was pipetted into the separatory funnel. The samples were mixed with methylene blue prior to chloroform extraction. The organic layer was then filtered through a phase separator filter paper (Whatman 1PS). The filtrates (chloroform + methylene blue) were then checked for their absorbances using a UV Spectrophotometer at the wavelength of $652 \mathrm{~nm}$. A series of SDS solution at concentration of $10 \mathrm{ppm}, 7 \mathrm{ppm}, 5 \mathrm{ppm}, 3 \mathrm{ppm}, 2 \mathrm{ppm}$, and $1 \mathrm{ppm}$ were prepared and extracted using the same method and the data obtained were used for plotting a calibration curve and to obtain a linear regression. The concentration of the samples was then calculated using the calibration curve.

\section{Characterization of Kapok fiber}

\section{Results and Discussion}

Kapok fiber used in this study was studied using FTIR instrument. Generally, plant wax consists of n-alkanes, smaller portion of alcohols, fatty acids, aldehydes, ketones and n-alkyl esters. The following primary absorption peaks can be observed, where $2915.80 \mathrm{~cm}^{-1}$, corresponds to the asymmetric and symmetric aliphatic $\mathrm{CH}_{2}$ and $\mathrm{CH}_{3}$ stretching which can be associated with the presence of plant wax. The peaks around $1735.60 \mathrm{~cm}^{-1}$ is due to the presence of carbonyl group $(\mathrm{C}=\mathrm{O})$ in the ester bonds, which are alleged to be associated with the aliphatic aldehydes, esters and ketones of Kapok wax. The band around 1504 and $1592 \mathrm{~cm}^{-1}$ are corresponds to C-O stretching in lignin. Table 1 shows the characterization of Kapok fiber using FTIR instrument. 
Table 1. FTIR absorption peaks of Kapok fiber used in the current study and those reported in literature

\begin{tabular}{lccccc}
\hline $\begin{array}{l}\text { Non- } \\
\text { free OH }\end{array}$ & $\begin{array}{c}\text { Symmetric and } \\
\text { Asymmetric CH } \\
\text { \& } \mathbf{C H}_{\mathbf{3}}\end{array}$ & $\begin{array}{c}\mathbf{C}=\mathbf{O} \text { : Ketone, Carboxylic, } \\
\text { Ester in Lignin \% Acetyl } \\
\text { Ester in Xylan }\end{array}$ & $\begin{array}{c}\text { Aromatic } \\
\text { Ring Carbon } \\
\text { Skeleton }\end{array}$ & $\begin{array}{c}\text { C-H and C-O } \\
\text { Bending }\end{array}$ & Reference \\
\hline 3410 & 2914 & 1740 & $1504 \& 1602$ & $1373 \& 1245$ & {$[18]$} \\
- & 2891 & $1745 \& 1234$ & - & 1017 & {$[12]$} \\
3350 & 2918 & $1738 \& 1238$ & - & 1037 & {$[19]$} \\
3340 & 2906.59 & 1725.66 & - & $1366.28 \&$ & {$[20]$} \\
& & & & 1231.85 & \\
& 2915.80 & 1735.60 & $1504 \& 1592$ & $1369.19 \&$ & Current \\
& & & & 1238.06 & Study \\
\hline
\end{tabular}

\section{Removals of oil and grease and anionic surfactants using Kapok fiber}

Table 2, Figure 1 and Figure 2 shows the removal efficiency of anionic surfactants and oil and grease at $\mathrm{pH} 7.0$ at room temperature using Kapok fiber. It was observed that for oil and grease, there was $100 \%$ removal using $0.1 \mathrm{~g}$ of Kapok at contact time of 10 minutes. This finding was also observed in another study using natural Kapok fiber [13]. On the other hand, the highest removal of anionic surfactants is $46 \%$, using $3.0 \mathrm{~g}$ of Kapok fiber at a contact time of 10 minutes. The pattern shows that Kapok fiber does not need longer contact time to perform efficiently and discreetly remove oil and grease and anionic surfactants.

Table 2. Average concentration and average removals of samples

\begin{tabular}{lccc}
\hline $\begin{array}{l}\text { Sample } \\
\text { Dosage (g) }\end{array}$ & Time (min) & $\begin{array}{c}\text { Average } \\
\text { Concentration }(\mathbf{p p m})\end{array}$ & $\begin{array}{c}\text { Average } \\
\text { Removals (\%) }\end{array}$ \\
\hline \multirow{3}{*}{$0.1 \mathrm{~g}$} & 10 & $33.3( \pm 11.5)$ & $61.5( \pm 13.3)$ \\
& 30 & $33.3( \pm 11.5)$ & $61.5( \pm 13.3)$ \\
& 60 & $40.0( \pm 0.0)$ & $53.8(( \pm 0.0)$ \\
$1.0 \mathrm{~g}$ & 10 & $0.0( \pm 0.0)$ & $100.0( \pm 0.0)$ \\
& 30 & $13.3( \pm 11.5)$ & $84.6( \pm 13.3)$ \\
& 60 & $26.7( \pm 11.5)$ & $69.2( \pm 13.3)$ \\
$3.0 \mathrm{~g}$ & 10 & $33.3( \pm 11.5)$ & $61.5( \pm 13.3)$ \\
& 30 & $13.3( \pm 11.5)$ & $84.6( \pm 13.3)$ \\
& 60 & $26.7( \pm 11.5)$ & $69.2( \pm 13.3)$ \\
\hline
\end{tabular}

Moreover, it was found that as the contact time increased, the efficiency for anionic surfactants removals decreased. This may be due to weak hydrophobic interactions between the waxy layers of Kapok fiber with the hydrocarbon tails of the anionic surfactants. Meanwhile, the efficiency for oil and grease removal does not differ much with time. In addition, the result shows that using shorter contact time will be preferable for Kapok fiber to perform efficiently.

In term of the removal efficiency, the hollow lumen structure of Kapok fiber and the waxy surface can be held responsible for its sorption capacity [15]. Moreover, for oil removal, the oil collected or entrapped in the fiber assembly can be due to the oil being retained in an internal lumen, and the oil entrapped in the voids between fibers (also known as inter-capillary fibers) [21]. On the other hand, for the absorption of anionic surfactants, it may be due to interaction of the alkyl groups of the surfactants with the waxy surface of Kapok fiber [22]. The interaction may mimic the hydrophobic interaction and van der Waals forces that may occur between the oils and the waxy 
layer of the Kapok fibers in oil absorption onto Kapok [15] when the hydrocarbon chains of the SDS molecules are aligned with the hydrophobic waxy surface of the Kapok fibers.

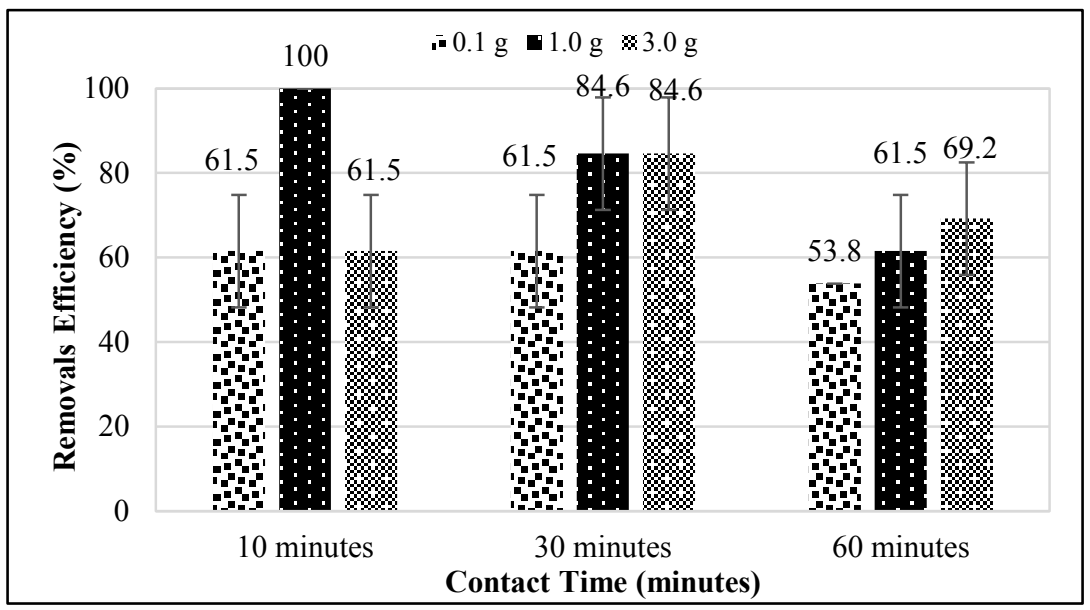

Figure 1. Removal efficiency of oil and grease using Kapok fiber

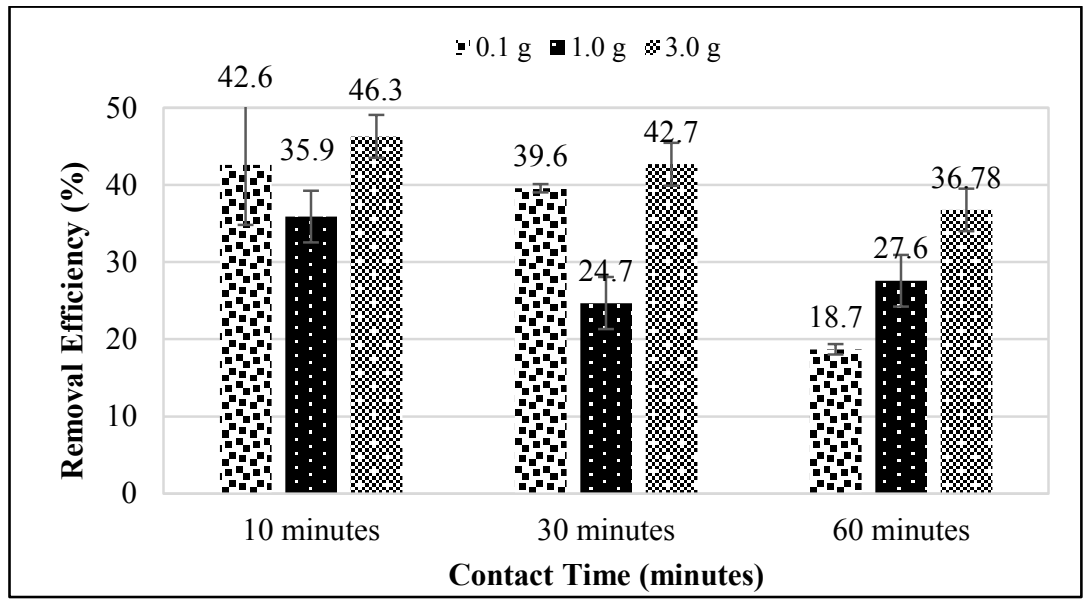

Figure 2. Removal efficiency of anionic surfactants using Kapok fiber

However, the results show that the removals of anionic surfactants were not as high as oil and grease removal. This may be due to weak interactions between the anionic surfactants and the waxy layers of the Kapok fibers as the hydrophobic interaction and van der Waals forces of attraction is rather weak and easily disturbed [23]. Moreover, the polar head of SDS molecule will be exposed to water. The forces of attraction between the negatively charged polar head of the anionic surfactants will pull the molecule back into the water, thus weakening and may destroy for the hydrophobic interaction of the alkyl group of SDS.

\section{Conclusion}

Kapok fiber as a natural sorbent shows high efficiency in oil and grease removals and promising application in anionic surfactants removal. The waxy layers of Kapok fiber are known to provide hydrophobic interaction with oil and grease. This work provides findings on the efficiency of the Kapok fibers in removing oil and grease and anionic surfactants. The new findings of Kapok fiber in removing anionic surfactants will provide new knowledge 
Muhammad Shahrul Shafendy \& Nor Haslina: REMOVAL OF OIL AND GREASE AND ANIONIC

SURFACTANTS IN SYNTHETIC CAR WASH WASTEWATER

USING KAPOK FIBER: A BATCH-SCALE STUDY

of interactions between anionic surfactants and the Kapok fiber. The study is still ongoing, and further discussions will be shared in the future.

\section{Acknowledgement}

This work was funded by Ministry of Higher Education of Malaysia under the Fundamental Research Grant Scheme (FRGS), Vot No: 1565.

\section{References}

1. Bhatti, Z. A., Mahmood, Q., Raja, I. A., Malik, A. H., Khan, M. S. and Wu D. (2011). Chemical oxidation of carwash industry wastewater as an effort to decrease water pollution. Physical Chemistry Earth, 36(9-11): 465469.

2. Shahbazi, R., Kasra-Kermanshahi, R., Gharavi, S., Moosavi- Nejad, Z. and Borzooee, F. (2013). Screening of SDS-degrading bacteria from car wash wastewater and study of the alkylsulfatase enzyme activity. Iranian Journal of Microbiology, 5(2): 153-158.

3. Lau, W. J., Ismail, A. F. and Firdaus, S. (2013). Car wash industry in Malaysia: Treatment of car wash effluent using ultrafiltration and nanofiltration membranes. Separation Purification Technology, 104: 26-31.

4. Jönsson, C., and Jönsson, A. S. (1995). The influence of degreasing agents used at car washes on the performance of ultrafiltration membranes. Desalination, 100(1-3): 115-123.

5. Kwach, B. O. and Lalah, J. O. (2009). High concentrations of polycyclic aromatic hydrocarbons found in water and sediments of car wash and kisat areas of Winam Gulf, Lake Victoria-Kenya. Bulletin Environmental Contamination Toxicology, 83(5): 727-733.

6. Wu, L., Ge, G. and Wan, J. (2009). Biodegradation of oil wastewater by free and immobilized Yarrowia Lipolytica W29. Journal of Environmental Science, 21(2): 237-242.

7. Perkowski, J., Bzdon, S. A., Bulska and Jóźwiak, W. K. (2006). Decomposition of detergents present in carwash sewage by titania photo-assisted oxidation. Polish Journal of Environmental Study, 15(3): 457-465.

8. Aloui, F., Kchaou, S. and Sayadi, S. (2009). Physicochemical treatments of anionic surfactants wastewater: effect on aerobic biodegradability. Journal of Hazardous Material, 164(1): 353-359.

9. Merta, J. and Stenius, P. (1999). Interactions between cationic starch and mixed anionic surfactants. Colloids Surfaces A Physicochem. Engineering Aspect, 149(1-3): 367-377.

10. Nielsen, A. D. Borch, K. and Westh, P. (2000). Thermochemistry of the specific binding of C12 surfactants to bovine serum albumin. Life Science, 1479: 321-331.

11. Zheng, Y., Wang, J., Zhu, Y. and Wang, A. (2015). Research and application of kapok fiber as an absorbing material: A mini review. Journal of Environmental Science, 27: 21-32.

12. Abdullah, M. A., Rahmah, A. U. and Man, Z. (2010). Physicochemical and sorption characteristics of Malaysian Ceiba pentandra (L.) Gaertn. as a natural oil sorbent. Journal of Hazardous Materials, 177 (1-3): 683-691.

13. Rahmah, A. U. and Abdullah, M. A. (2011). Evaluation of Malaysian Ceiba pentandra (L.) Gaertn for oily water filtration using factorial design. Desalination, 266(1-3): 51-55.

14. Hori, S., Flavier, K. and Kuga, M. E. (2000). Excellent oil Absorbent Kapok Ceiba pentandra (L.) Gaertn fiber: Fiber structure, chemical characteristics, and application. Japan Wood Resource Society, 46: 401-404.

15. Lim, T. T. and Huang, X. (2007). Evaluation of Kapok (Ceiba pentandra (L.) Gaertn.) as a natural hollow hydrophobic-oleophilic fibrous sorbent for oil spill cleanup. Chemosphere, 66(5): 955-963.

16. Adak, A., Bandyopadhyay, M. and Pal, A. (2005). Removal of anionic surfactant from wastewater by alumina: A case study. Colloids Surfaces A Physicochem. Engineering Aspect, 254(1-3): 165-171.

17. APHA. (2005). Standard methods for the examination of water and wastewater. American Public Health Association, Washington, D.C.

18. Wang, J., Zheng, Y. and Wang, A. (2012). Effect of Kapok fiber treated with various solvents on oil absorbency. Industrial Crops Product, 40(1): 178-184.

19. Rengasamy, R. S., Das, D. and Praba Karan, C. (2011). Study of oil sorption behavior of filled and structured fiber assemblies made from polypropylene, Kapok and Milkweed fibers. Journal of Hazardous Materials, 186(1): 526-532.

20. Ismail, Z. (2013). Comparative study on raw and modified Kapok fibers as sorbent materials for oil sorption. Thesis Universiti Teknologi PETRONAS, Malaysia. 
21. Wang, J., Zheng, Y. and Wang, A. (2012). Superhydrophobic Kapok fiber oil-absorbent: Preparation and high oil absorbency. Chemical Engineering Journal, 213: 1-7.

22. Zhang, R. and Somasundaran, P. (2006). Advances in adsorption of surfactants and their mixtures at solid/solution interfaces. Advance Colloid Interface Science, 123: 213-229.

23. Stone, A. (2013). The theory of intermolecular forces. OUP Oxford. 